\title{
Communitization Management in Kulina to Increase Customer After Rebranding
}

\author{
$1^{\mathrm{st} *}$ Erwan Sudiwijaya \\ Communication Department \\ Universitas Muhammadiyah Yogyakarta \\ Yogyakarta, Indonesia \\ erwansudiwijaya@umy.ac.id
}

\author{
$2^{\text {nd }}$ Kuskridho Ambardi \\ Communication Department \\ Universitas Gadjah Mada \\ Yogyakarta, Indonesia \\ ambardi5000@yahoo.com
}

\begin{abstract}
The background of this research comprises 1 . Social media that gives customers the opportunity to interact with brands can be used to build long-term relationships. 2 . consummers want to connect with other consumers not with companies 3. culinary sub-sector records a $41 \%$ contribution to the creative economy's gross domestic product 4 . Playing in the same niche, Kulina is founded in 2015 as a culinary information broker 5. In September 2017 Kulina re-brands with a focus on selling one-day service, by contributing $60 \%$ of new customers to equal Berrykitchen's daily order number of 3,000 orders per day in January 2018. The statement of the problem in this research relies on how does Kulina manage $60 \%$ of new customers to increase sales after rebranding? This research is qualitatively designed. with descriptive analysis methods. The research data which is used is descriptive research data, where the researcher collects data through field study techniques (interviews, observation, and document collection). The result reveals, peer to peer relationship is developed into a sharing community by empowering customers through collaboration with customers that is happened organically and non-organically.
\end{abstract}

Keywords-Communitizatin, digital marketing communication, social media, brand communication

\section{INTRODUCTION}

The 4th Industrial Revolution came up with the idea of connecting all elements of the value chain and the daily lives of consumers into a single system through the "Internet" information technology system [1]. The traditional hierarchical structure of the economy has developed into an internet-based network economy that involves consumers to become part and manage their own value chains.Every consumer has the potential to become a producer with personal assets as a commodity [2]. Since the beginning of 2000, information technology has developed into a new wave of technology that enables connectivity and interactivity of individuals and groups.

Social media develops with its wider user and digitally begins to influence brand marketing communication on its target audience.This triggered a lot of research in the field of digital marketing communications to observe and analyze this phenomenon. Valos et al., [3] study on the service industry reveals the unique characteristics of social media, namely interactivity and individualization, the integration of channels of communication and distribution, proximity and information gathering that influenced the traditional marketing communication framework.
Social media that gives customers the opportunity to interact with brands can be used to build long-term relationships. More deeply, Yadav et al., [4] reviews this through a literature review, this study suggests companies to make attractive social media applications in order to do not make it monotonous and disruptive so that they can become an inseparable part of the customer's daily life.

In Tribes, Seth Godin argues that consumers want to connect with other consumers not with companies. Companies that want to embrace new trends must accommodate these needs and help consumers connect with each other in the community.This process is called communitization.

The attitude of openness, honesty and egalitarianism is the foundation and adhesive of each member to interact with one another, trust and mutuality among digital consumers are said to replace competition and hyper-individualism which are the characteristics of the economic system of capitalism which slowly begins to lose its legitimacy. [5].

Customer involvement in collaboration according to Smith, PR, \& Zook, Z [6] will increase the emotional connection with the brand where they will express their sentiments and opinions towards a brand through repeated visit patterns, purchases, product ratings, reviews, blogs, discussion forums and ultimately recommend brands to other consumers in the surrounding environment.

To be able to collaborate and interact horizontally, according to Kotler, et al. [7] brand managers should understand consumer appreciation for brand efforts for cocreation, communitization and character formation, plus digital marketing communication. [8]

A variety of information products are marketed through e-commerce easily and practically, e-commerce as an information broker involves everyone to take part as a seller and buyer at the same time armed with a smart phone. It is not surprising if this stimulates the creativity of its users to create innovation. One of the products that drives the growth of Indonesia's creative economy is culinary efforts. Based on a survey made by the Indonesian Creative Economy Agency and the Central Statistics Agency in 2016, the culinary subsector records a $41 \%$ contribution to the creative economy's gross domestic product. [9]

The growth of culinary e-commerce in Indonesia is initiated by food delivery services as a solution for restaurants that do not have delivery services. Foodpanda 
comes as the first German start-up which spread its wings to Indonesia.Then it is followed by GoFood as an information broker for restaurant partners with networks tens of thousands of GoJek drivers to run services between GoFood food. The rapid growth can be seen from 37,000 restaurant and restaurant partners who have joined the GoFood service and make it the leader in the category of food delivery services in major cities such as Bandung and Jakarta. [10]

Playing in the same niche, Kulina is founded in 2015 that comes with a different concept. The marketplace as a culinary information broker connects wedding reception catering partners from various places of Jakarta, freight forwarding services and customers who need food. Kulina sets the price of food and shipping costs at a price of Rp. 30,000 and can be reduced depending on the number of customers in the building. [11]

In September 2017 Kulina re-brands with a focus on selling one-day service, one lunch menu and starts orders with 150 orders. The number of orders meet a significant increase during November and December by maximizing the internet as a marketing communication medium. It is proved by contributing $60 \%$ of new customers to equal Berrykitchen's daily order number of 3,000 orders per day in January 2018

\section{METHOD}

In the process of organizing this research, researcher uses qualitative research methods with descriptive analysis methods. The research data which is used is descriptive research data, where the researcher collects data through field study techniques (interviews, observation, and document collection).In qualitative research, researcher determines that informants are people who are directly related to the object of research. The informants are Thomas Dian, Digital Marketing Manager, Fira, Customer Experience Head and Rani - Supervising Delivery.

Observations are made to see Kulina's digital marketing communication activities on Instagram @kulina.id accounts during September 2017 - January 2018 and document searches are done via the internet on Instagram social media sites through searches with keywords \#kulina and other sites that contained information about kulina based on searches on google with the keyword kulina.

These data are reduced by the researcher into a data presentation that has been grouped based on the research model. Then the data are compared with the theoretical basis to produce conclusions and suggestions.

In this study, the researcher will check the validity by using the triangulation method after the data is obtained. The triangulation method is used when the researcher compares the information from the interview with observation and other documentation sources.

\section{RESULT}

The desire of consumers to connect with each other is the basis of the Communitization concept based on an open, honest and egalitarian attitude. Today, trust and mutuality between digital consumers replace competition and hyperindividualism which are the hallmarks of the economic system of capitalism which is slowly beginning to lose its legitimacy [5]. In Kulina the communication patterns on
Instagram occur in an egalitarian manner where customer questions are often answered by other customers voluntarily and often help to explain Kulina's new programs.

Online social networks play an important role in decision support systems and for product diffusion [12], this network is an online brand community with the same goal but on the other hand they are also heterogeneous in many ways. Özbölük, T., \& Dursun, Y. [13] identified five types of brand community members namely learners, pragmatists, activists, opinion leaders and evangelists. Opinion leaders play an important role in promoting product or brand-related information to consumer partners [14], publish information and influence public opinion on the microblog platform [15] attitude building [16] branding with relevant content support [17]. Therefore opinion leaders are used to promote products value and experimental (hedonic) and functional (utilitarian) services in various online forums [18] because Opinion Leaders' personal characteristics facilitate their commitment to the behavior of sharing brand content [19] plus the perception of popularity caused by influencers increases leadership opinions [20]

Opinion leaders according to Oetting, M., [21] want to be heard by brands, so giving them a space in the company such as listening to their opinions and criticisms is a brand effort to prove that their opinions are important and give them strong reasons to spread the information. When they become VIP for brands with ego, being privileged and having exclusive information will increase authority as opinion leaders in their peer groups.

According to Rusticus, S., [22] the existence of opinion leaders who support this brand benefits the brand in their efforts to communicate on the customer network. Brand supporters are regular clients, customers, or target audiences who do not have the power of special opinion, but really like the brand. Thus, they recommend it to others. One way to look at brand supporters is through the brand advocacy pyramid.

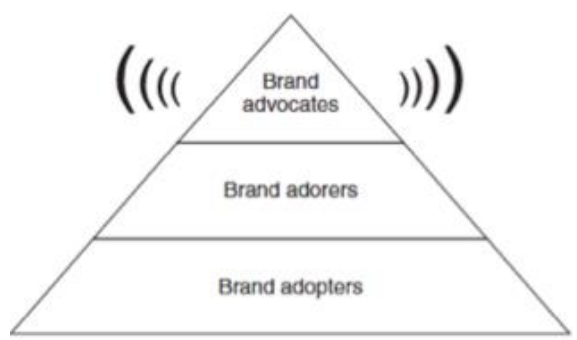

Fig. 1. Brand Supporting Hierarchy

On the pyramid base is the majority of the target audience base. It can be called brand adopters.Brand adopters are consumers who are quite satisfied with the brand experience to become ordinary users.In the middle are brand lovers who show high loyalty to the brand. Then, at the top of the pyramid is brand supports. They are consumers who are very satisfied with the brand experience. Supporters of this brand are advocates for brands that encourage to the growth. There is an interest in every marketer to increase the proportion of supporters in the brand pyramid while encouraging supporters of existing brands to do more advocacy for larger people. 
A high-level critical customer at Kulina is a loyal and militant customer. They become opinion leaders who actively interact with Kulina's customer community on social media, such as Instagram. Always become responsive and seek solutions as soon as possible from customer complaints emerge satisfaction that they feel. Moreover, it grows customer loyalty with Kulina Same with Sivadas et al, [23] research the best overall performance is the key to encouraging positive word of mouth according to research results.

The results of Harris et al [24] study on female consumer behavior shows that a strong relationship between customer perceived value and word of mouth initiation indicates the importance of increasing customer perceptions about value that they have. In Kulina, brand adopters are passive customers who use Kulina products without expressing their positive / negative experiences. Brand lovers are Kulina customers who express the experience of using products on social media in the form of user generated content and comment. Brand supporters are customers who have high interaction intensity with Kulina and with other customers as opinion leaders.

The peer-to-peer community does not have hierarchy (egalitarianism) and it is in line with the concept of sharingaccording to John, N. A.,[5]. The pattern of interaction on peer-to-peer networks builds collaborative consumption as a movement rooted in internet technology. The peer to peer network in Kulina is built on Instagram's social media platform. The interaction takes place in an egalitarian manner where the flow of communication does not only take place between the brand and the customer but also it is more common happened among customers and opinion leaders who are representations of Kulina.

Collaboration between Kulina customers takes place organically and non-organically. On Instagram, Kulina customers make user generated content about Kulina to express their emotions organically. Explained by sentiment analysis in Liu, et al. [25] research, user generated content is related to brands that expresses emotion. Customers who are not happy in making the content are three times more to express their complaints. Instead, happy customers create content to praise the strengths and strengths of brands on social media. Consumer behavior shows that customers do not pay much attention to incentives for brand demand in creating user generated content [26]. The credibility of user generated content of other customers view is determined by the value of information, source credibility and the level of similarity between users and content creators. [27].

In contrast with the incentive offer, Kulina motivates customers to invite people around them to subscribe using the reveral code program and change program nonorganically. In the referral code program, the customer can recommend the code to prospective customers to get a free order in the first order. The customer who recommend it also gets a free order. In the change program, customers can invite friends in one building to subscribe Kulina. When ordering together, the distribution costs will be cheaper and will be returned to the customer's deposit savings that recommends his friends.

\section{CONCLUSION}

Communitization is built on Instagram social media platform and it is driven by customers. Brand adopters are passive customers who use products without expressing positive / negative experiences. Brand lovers are Kulina customers who express the experience of using products on social media in the form of user generated content and comment. Brand supporters are customers who have high interaction intensity with Kulina and with other customers as opinion leaders.

Opinion Leaders appear organically from customers who often give complaint and get quickly responds and solutions from customer experience. In Kulina's social media network, interactions occur without hierarchies even the Chief Level appears with a personal account to be directly involved in the discussion. This peer to peer relationship is developed into a sharing community by empowering customers through collaboration with customers that is happened organically and non-organically. Organically on Instagram, customers make user generated content to express their emotions. Kulina motivates customers to invite people around them to subscribe using the reveral code program and change program non-organically.

\section{REFERENCES}

[1] Kinzel, H. (2016). Industry 4.0 - Where Does This Leave The Human Factor? Conference: 27th Annual Conference of Human Dignity and Humiliation Studies. Retrieved from https://www.researchgate.net/publication/308614137_Industry_40_Where does this leave the Human Factor

[2] Oskam, J., \& Boswijk, A. (2016). Airbnb: The future of networked hospitality businesses. Journal of Tourism Futures, 2(1), 22-42. doi:10.1108/jtf-11-2015-0048

[3] Valos, M. J., Habibi, F. H., Casidy, R., Driesener, C. B., \& Maplestone, V. L. (2016). Exploring the integration of social media within integrated marketing communication frameworks. Marketing Intelligence \& Planning, 34(1), 19-40. doi:10.1108/mip-09-20140169

[4] Yadav et al., (2015) Yadav, M., Joshi, Y., \& Rahman, Z. (2015). Mobile Social Media: The New Hybrid Element of Digital Marketing Communications. Procedia - Social and Behavioral Sciences, 189, 335-343. doi:10.1016/j.sbspro.2015.03.229

[5] John, N. A. (2013). Sharing, Collaborative Consumption and Web 2.0. Media@LSE. London School of Economics and Political Science. Retrieved from http://www.lse.ac.uk/media-andcommunications/assets/documents/research/working-paperseries/EWP26.pdf

[6] Smith, P. R., \& Zook, Z. (2011). Marketing Communications: Integrating offline and online with social media. London, Philadelphia, Daryaganj, Kogan Page.

[7] Kotler, P., Kartajaya, H., \& Setiawan, I. (2010). Marketing 3.0: From products to customers to the human spirit. New Jersey, John Wiley \& Sons.

[8] Vaquero, A. D., \& Calle, P. D. (2013). The collaborative consumption : a form of consumption adapted to modern times. Revista De Estudios Económicos Y Empresariales, Núm. 25, 15-30. Retrieved from https://core.ac.uk/download/pdf/72044275.pdf

[9] Salam, F., \& Hasan, A. M. (2017, August 03). Konsumsi medsos membentuk pola makan generasi $Z$. Retrieved from https://tirto.id/konsumsi-medsos-membentuk-pola-makan-generasi-zctPR

[10] Pramisti, N. Q., Bhaskara, L. A., \& Ign. (2018, April 19). Belajar dari kegagalan Foodpanda di Indonesia. Retrieved from https://tirto.id/belajar-dari-kegagalan-foodpanda-di-indonesia-bDwh

[11] Triwijanarko, R. (2018, January 03). Meraba masa depan layanan food delivery startup di Indonesia. Retrieved from 
http://marketeers.com/meraba-masa-depan-layanan-food-deliverystartup-di-indonesia/

[12] Jain, L., \& Katarya, R. (2018). A Systematic Survey of Opinion Leader in Online Social Network. 2018 International Conference on Soft-Computing and Network Security (ICSNS). doi: 10.1109/icsns.2018.8573639

[13] Özbölük, T., \& Dursun, Y. (2017). Online brand communities as heterogeneous gatherings: a netnographic exploration of Apple users. Journal of Product \& Brand Management, 26(4), 375-385. doi: 10.1108/jpbm-10-2015-1018

[14] Haron, H., Johar, E. H., \& Ramli, Z. F. (2016). Online opinion leaders and their influence on purchase intentions. 2016 IEEE Conference on e-Learning, e-Management and e-Services (IC3e). doi: $10.1109 / \mathrm{ic} 3 \mathrm{e} .2016 .8009059$

[15] Li, H., Huang, S., \& Sun, G. (2015). An opinion leader perceptual model based on PageRank algorithm. 2015 International Conference on Behavioral, Economic and Socio-Cultural Computing (BESC). doi: 10.1109/besc.2015.7365973

[16] Gómez-Suárez, M., Quinones, M., \& Yagúe, M. J. (2016). Store brand evaluative process in an international context. International Journal of Retail \& Distribution Management, 44(7), 754-771. doi: 10.1108/ijrdm-11-2015-0168

[17] Lipiäinen, H. S. M., \& Karjaluoto, H. (2015). Industrial branding in the digital age. Journal of Business \& Industrial Marketing, 30(6), 733-741. doi: 10.1108/jbim-04-2013-0089

[18] Lin, H.-C., Bruning, P. F., \& Swarna, H. (2018). Using online opinion leaders to promote the hedonic and utilitarian value of products and services. Business Horizons, 61(3), 431-442. doi: 10.1016/j.bushor.2018.01.010

[19] Grissa, K. (2016). What makes opinion leaders share brand content on professional networking sites (e.g LinkedIn, Viadeo, Xing,
SkilledAfricans...). 2016 International Conference on Digital Economy (ICDEc). doi: 10.1109/icdec.2016.7563139

[20] Veirman, M. D., Cauberghe, V., \& Hudders, L. (2017). Marketing through Instagram influencers: the impact of number of followers and product divergence on brand attitude. International Journal of Advertising, 36(5), 798-828. doi: 10.1080/02650487.2017.1348035

[21] Oetting, M. (2006). How to manage connected marketing. In Kirby, J., \& Marsden, P (Eds), Connected marketing, the viral, buzz and word of mouth revolution (pp. 232-265). Oxford, Elsevier Ltd..

[22] Rusticus, S. (2006). Creating brand advocates. In Kirby, J., \& Marsden, P (Eds), Connected marketing, the viral, buzz and word of mouth revolution (pp. 47-58). Oxford, Elsevier Ltd.

[23] Sivadas, E., \& Jindal, R. P. (2017). Alternative measures of satisfaction and word of mouth. Journal of Services Marketing, 31(2), 119-130. doi:10.1108/jsm-09-2015-0282

[24] Harris, Patricia, and Nasim Alsadat Khatami. (2017) "Antecedents of word of mouth behaviour among female grocery shoppers in Iran." Journal of Islamic Marketing, 8(1), pp. 2-15., doi:10.1108/jima-022015-0014.

[25] Liu, X., Burns, A. C., \& Hou, Y. (2017). An investigation of brandrelated user-generated content on twitter. Journal of Advertising, 46(2), 236-247. doi:10.1080/00913367.2017.1297273

[26] Malthouse, E. C., Calder, B. J., Kim, S. J., \& Vandenbosch, M. (2016). Evidence that user-generated content that produces engagement increases purchase behaviours. Journal of Marketing Management, 32(5-6), 427-444. doi:10.1080/0267257x.2016.1148066

[27] Herrero, Á, Martín, H. S., \& Hernández, J. M. (2015). How online search behavior is influenced by user-generated content on review websites and hotel interactive websites. International Journal of Contemporary Hospitality Management, 27(7), pp. 1573-1597. doi:10.1108/ijchm-05-2014-0255 